\title{
MANAJEMEN DAN REKAYASA LALU LINTAS PADA HARI PASAR DI PASAR KOTO BARU KABUPATEN TANAH DATAR
}

\author{
Ni Putu Wulan Andreyani ${ }^{1}$, I Made Suraharta ${ }^{2}$, Irfan Hardiansyah ${ }^{3}$ \\ 1), 2), ${ }^{3)}$ PTDI-STTD \\ Email: isuraharta@ptdisttd.ac.id
}

\begin{abstract}
The smoothness of traffic in each region absolutely must be supported by the ability of the infrastructure to meet existing demand. However, the provision of good infrastructure without accompanied by traffic management will not generate traffic optimal performance. Both of these must be met simultaneously if we want the traffic performance optimally. Tanah Datar regency is being developed so that the mobility of trade and services is high quality. Koto Baru Market is a market that has a layout that is strategic to be on the road section that has the function of roads as arterial roads and the road status as a national road market has activity level ride high on the market so that roads in the region this market has a volume of traffic tall one. Trip generation and trip attraction on a market day in the Koto Baru Market contributed to the high movement of vehicles and pedestrians in the area that is growing as the growing center of trade and services and the many distractions of traffic appeared on the road section as the emergence of parking vehicles in the roadside and road users are less orderly, especially pedestrians. Seeing this situation, the need for management and traffic engineering to optimize the use of existing infrastructure, improve the efficiency of traffic movement thoroughly with a high level of accessibility as well as to balance the demand for infrastructure. Management and traffic engineering practices should consider the effect on the performance of the traffic. Based on the analysis, the handling scenarios are applied can reduce $v / c$ ratio of 0.88 into 0.72 in streets that most troubled the existing condition. In the implementation of the handling scenarios, the support of all parties concerned is absolutely necessary so that the Government of Tanah Datar able to disseminate the scenario that is applied to the community and the legal rigor emphasis in its implementation in the field.
\end{abstract}

Keywords: Management and traffic engineering, V/C Ratio, Speed, Density, Parking, Pedestrian, Time Windows of Goods Transport

\begin{abstract}
ABSTRAK
Kelancaran Lalu Lintas pada setiap kawasan mutlak harus didukung oleh kemampuan infrastruktur dalam memenuhi permintaan yang ada. Akan tetapi, penyediaan infrastruktur yang baik tanpa dibarengi oleh manajemen lalu lintas tidaklah akan menghasilkan kinerja lalu lintas yang optimal. Kedua hal tersebut harus dipenuhi secara bersamaan jika kita menginginkan kinerja lalu lintas secara optimal. Kabupaten Tanah Datar merupakan kabupaten yang sedang berkembang sehingga mobilitas perdagangan dan jasa cukup tinggi. Pasar Koto Baru merupakan pasar yang mempunyai letak yang cukup strategis berada pada ruas jalan yang memiliki fungsi jalan sebagai jalan arteri dan status jalan sebagai jalan nasional Pasar ini memiliki tingkat aktifitas perjalanan yang tinggi pada hari pasar sehingga ruas jalan di kawasan pasar ini memiliki volume lalu lintas yang tinggi. Bangkitan dan tarikan perjalanan pada hari pasar di Pasar Koto Baru ini menyebabkan tingginya pergerakan kendaraan dan pejalan kaki di kawasan tersebut yang terus bertambah seiring semakin berkembangnya pusat perdagangan dan jasa dan banyaknya gangguangangguan lalu lintas muncul pada ruas jalan tersebut seperti munculnya parkir kendaraan di badan jalan dan kurang tertibnya pengguna jalan terutama pejalan kaki. Melihat kondisi ini perlu adanya manajemen dan rekayasa lalu lintas untuk mengoptimalkan penggunaan prasarana yang ada, meningkatkan efisiensi pergerakan lalu lintas secara menyeluruh dengan tingkat aksesibilitas yang tinggi serta menyeimbangkan permintaan terhadap prasarana yang ada. Manajemen dan rekayasa lalu lintas yang diterapkan harus mempertimbangkan pengaruh terhadap unjuk kerja lalu lintas. Berdasarkan hasil analisa, maka skenario penanganan yang diterapkan dapat menurunkan v/c ratio dari 0,88 menjadi 0,72 di ruas jalan yang paling bermasalah pada kondisi eksisting. Dalam pelaksanaan skenario penanganan tersebut, maka dukungan dari
\end{abstract}


semua pihak yang terkait mutlak diperlukan sehingga Pemerintah Kabupaten Tanah Datar mampu mensosialisasikan skenario yang diterapkan kepada masyarakat dan melakukan penekanan ketegasan hukum dalam pelaksanaannya di lapangan.

Kata Kunci: Manajemen dan Rekayasa Lalu Lintas, V/C Ratio, Kecepatan, Kepadatan, Parkir, Pejalan Kaki, Waktu Operasi Angkutan Barang

\section{PENDAHULUAN}

Pesatnya pertumbuhan perdagangan dan jasa telah mendorong perkembangan perekonomian yang semakin pesat. Dengan adanya peningkatan aktivitas secara otomatis akan berakibat juga terhadap peningkatan volume lalu lintas terutama pada ruas jalan yang berada di sekitar pembangunan pusat perdagangan dan jasa. Dengan tidak adanya pengendalian dan perencanaan yang optimal terhadap penataan tata ruang akan semakin memperburuk permasalahan yang ada.

Kegiatan pada suatu kabupaten akan sangat tergantung dari sistem dan pelayanan transportasi yang berjalan pada kabupaten tersebut. Kabupaten dengan berbagai subsistem akan tertata dengan baik apabila didukung oleh kondisi transportasi yang baik pula. Suatu kabupaten yang tumbuh dan berkembang akan ditandai dengan semakin meningkatnya aktivitas dan mobilitas dari penduduknya. Untuk mengimbangi dan mendukung dari keseluruhan mobilitas tersebut diperlukan berbagai fasilitas dan sistem transportasi yang memadai, efektif dan efisien dan hal ini bukan merupakan pekerjaan yang mudah. Dalam setiap adanya pengambilan keputusan maupun kebijaksanaan harus selalu didasari oleh data yang terkini mengenai tingkat aktivitas kabupaten yang bersangkutan, agar hasil dari keputusan tepat sesuai dengan kebutuhan dan kondisi yang ada. Oleh karena itu diperlukan suatu studi-studi kelayakan yang dapat menunjang setiap kebijaksanaan yang akan diambil.

Kabupaten Tanah Datar adalah salah satu kabupaten yang berada di Provinsi Sumatera Barat yang letaknya sangat strategis karena merupakan wilayah perlintasan perjalanan orang maupun barang. Akibat letak dari Kabupaten Tanah Datar yang strategis maka banyaknya pusat perdagangan yang mendominasi pada setiap kecamatan di Kabupaten Tanah Datar.

Pasar Koto Baru merupakan salah satu pusat perdagangan dan jasa yang terletak di Kecamatan X Koto yang dilayani jaringan jalan dengan status nasional. Jaringan jalan tersebut merupakan Jalur Lintas Sumatera yang sebagian besar potensi mobilitas masyarakat tertinggi terdapat pada jaringan jalan tersebut. Saat ini Pasar Koto Baru mempunyai hari pasaran yakni pada hari senin dimana semua mobilitas masyarakat berpusat di Pasar Koto Baru. Kurang tertatanya kondisi Pasar Koto Baru pada saat hari pasar menyebabkan kesemrawutan yang dikarenakan terdapat aktivitas pedagang yang berjualan di bahu jalan, aktivitas pejalan kaki, kondisi parkir yang kurang teratur serta belum adanya pengaturan waktu proses bongkar muat angkutan barang sehingga sering terjadinya kemacetan lalu lintas pada hari pasar.

Untuk mengatasi hal tersebut, maka peneliti akan meneliti mengenai manajemen dan rekayasa lalu lintas pada Hari Pasar di Pasar Koto Baru Kabupaten Tanah Datar. Diharapkan dengan adanya manajemen rekayasa lalu lintas pada hari pasar di Pasar Koto Baru Kabupaten Tanah Datar dapat mengoptimalkan penggunaan prasarana yang ada, meningkatkan efisiensi pergerakan lalu lintas secara menyeluruh dengan tingkat aksesibilitas yang tinggi. 


\section{KAJIAN LITERATUR}

\section{Manajemen dan Rekayasa Lalu Lintas}

Berdasarkan Peraturan Menteri Perhubungan Nomor 96 Tahun 2015 menyatakan bahwa: Manajemen dan Rekayasa Lalu Lintas adalah serangkaian usaha dan kegiatan yang meliputi perencanaan, pengadaan, pemasangan, pengaturan, dan pemeliharaan fasilitas perlengkapan jalan dalam rangka mewujudkan, mendukung, dan memelihara keamanan, keselamatan, ketertiban, dan kelancaran lalu lintas. Dalam penelitian penulis lebih menekankan maksud melakukan manajemen rekayasa lalu lintas yaitu untuk kelancaran lalu lintas di jalan raya. Kelancaran lalu lintas dan angkutan jalan adalah sesuatu keadaan berlalu lintas dan penggunaan angkutan bebas dari hambatan dan kemacetan.

Menurut Duff (1961), manajemen dan rekaysa lalu lintas adalah suatu usaha pengaturan prasarana jalan yang ada dalam usaha memanfaatkan secara optimal prasarana jalan yang ada dalam usaha untuk memanfaatkan secara optimal prasarana jalan tersebut untuk kepentingan umum. Sejumlah tahap dapat diidentifikasi dalam model proses perekayasa lalu lintas. tahapan pertama adalah perumusan kebijakan pengendalian. Kebijakan pengendalian tergantung pada konteks jaringan, struktur biaya, pendapatan atau model utilitas, kendala operasional, dan kriteria keberhasilan. Tahapan kedua adalah pengamatan keadaan jaringan melalui serangkaian fungsi pemantauan. Tahap ketiga adalah karakterisasi lalu lintas dan analisis keadaan jaringan. Berbagai teknik kualitatif dan kuantitatif dapat ditrerapkanpada tahap karakteristik dan analisis (sumber: Bakhtiar,2014, MPLS dan Rekaysa lalu lintas dalam jaringan).

\section{Karakteristik Lalu Lintas}

a) Karakteristik Arus Lalu Lintas

1) Volume Lalu Lintas

Volume lalu lintas menunjukan jumlah kendaraan yang melintasi satu titik pengamatan dalan satu satuan waktu (hari, jam, menit). Volume lalu lintas yang tinggi membutuhkan lebar perkerasan jalan yang lebih besar, sehingga tercipta kenyamanan dan keamanan.

2) Kecepatan

Kecepatan adalah laju perjalanan yang biasanya dinyatakan dalam $\mathrm{km} / \mathrm{jam}$. Kecepatan dan waktu tempuh adalah pengukuran fundamental kinerja lalulintas dari sistem jalan eksisting, dan kecepatan adalah varabel kunci dalam perancangan ulang atau perancangan baru.

3) Kepadatan

Kepadatan didefinisikan sebagai jumlah kendaraan yang menempati panjang ruas jalan atau lajur tertentu, yang umumnya dinyatakan sebagai jumlah kendaraan per kilometer atau satuan mobil penumpang per kilometer $(\mathrm{smp} / \mathrm{km})$.

4) Hubungan antara volume, kecepatan dan kepadatan

Hubungan kecepatan dan kepadatan adalah linier yang berarti bahwa semakin tinggi kecepatan lalu lintas dibutuhkan ruang bebas yang lebih besar antar kendaraan yang mengakibatkan jumlah kendaraan perkilometer menjadi lebih kecil.

b) Karakteristik Prasarana

1) Kapasitas Ruas Jalan 
Kapasitas suatu ruas jalan dalam suatu sistem jalan adalah jumlah kendaraan maksimum yang memiliki kemungkinan yang cukup untuk melewati ruas jalan tersebut (dalam satu maupun dua arah) dalam periode waktu tertentu dan di bawah kondisi jalan dan lalu lintas yang umum.

2) Tingkat Pelayanan

Tingkat pelayanan (level of service) adalah ukuran kinerja ruas jalan yang dihitung berdasarkan tingkat penggunaan jalan, kecepatan, kepadatan dan hambatan yang terjadi. Dalam bentuk matematis tingkat pelayanan jalan ditunjukkan dengan V-C Ratio versus kecepatan $(\mathrm{V}=$ volume lalu lintas, $\mathrm{C}=$ kapasitas jalan).

3) Karakteristik Pengemudi

Karena persepsi dan kemampuan idividu pengemudi mempunyai sifat yang berbeda maka perilaku kendaraan arus lalu lintas tidak dapat diseragamkan, lebih lanjut arus lalu lintas akan mengalami perbedaan karakteristik akibat dari perilaku pengemudi yang berbeda dikarenakan oleh karakteristik lokal dan kebiasaan pengemudi.

4) Karakteristik Lingkungan

Menurut Suprapti (2012) dampak atau pengaruh keberadaan suatu infrastruktur jalan akan dapat menimbulkan dampak positif (manfaat) dan dampak negatif pada masyarakat. Dampak negatif akan menjadi faktor penghambat infrastruktur jalan, sedangkan dampak positif akan menjadi nilai tambah pada pembangunan atau peningkatan struktur jalan.

c) Karakterstik Parkir

Dalam setiap perjalanan yang menggunakan kendaraan maka akan diawali dan diakhiri pada tempat parkir, maka sarana untuk perpakiran akan tersebar pada setiap tempat baik di rumah maupun tempat - tempat tujuan manusia melakukan perpindahan. Menurut Ofyar Z. Tamrin (edisi kesatu) parkir merupakan salah satu unsur sarana yang tidak dapat dipisahkan dari sistem transportasi jalan raya secara keseluruhan.

1) Akumulasi Parkir

Merupakan banyaknya kendaraan yang parkir di suatu lokasi parkir pada selang waktu tertentu.

2) Volume Parkir

Merupakan total jumlah kendaraan yang telah menggunakan ruang parkir pada suatu lokasi pada suatu lokasi parkir dalam satu satuan waktu tertentu (hari).

3) Kapasitas Statis

Penyediaan kapasitas parkir yang akan disediakan atau yang akan ditawarkan untuk memenuhi permintaan parkir.

4) Kapasitas Dinamis

Kapasitas parkir yang tersedia (kosong selama waktu survei yang diakibatkan oleh kendaraan.

5) Durasi Parkir

Perhitungan Durasi Parkir tergantung pada rata - rata lamanya kendaraan yang parkir.

6) Indeks Parkir

Penggunaan parkir merupakan persentase penggunaan parkir pada setiap waktu atau perbandingan antara akumulasi dengan kapasitas. 
7) Tingkat Pergantian Parkir

Penggunaan ruang parkir yang merupakan perbandingan volume parkir untuk suatu periode waktu tertentu dengan jumlah ruang parkir/kapasitas parkir.

d) Karakteristik Pejalan Kaki

Pejalan kaki adalah orang yang melakukan aktifitas berjalan kaki dan merupakan salah satu unsur pengguna jalan. Penyeberang jalan dengan kondisi fisik yang mendapat perhatian khusus dapat dibagi menjadi 3, yaitu penyeberang yang cacat fisik, penyeberang anak-anak dan penyeberang usia lanjut.

e) Angkutan Barang

Angkutan Barang adalah kegiatan untuk mengangkut barang dari satu tempat ke tempat lainnya melalui darat dan menggunakan mobil barang sesuai dengan jenis layanan angkutan barang.

\section{METODE}

Langkah awal dalam rencana penelitian ini adalah dengan melakukan pengumpulan data baik yang bersifat kuantitatif maupun kualitatif. Data tersebut terdiri dari data sekunder dan data primer yang berasal dari survei kepada lapangan ataupun data yang berasal dari instansi atau Lembaga pemerintah terkait. Penelitian akan dilaksanakan di Pasar Koto Baru pada saat terjadi hari Pasar.

\section{PEMBAHASAN}

\section{Analisa Data Eksisting Pasar Koto Baru}

a) V/C Ratio Ruas Jalan Pada Hari Pasar

Tradisi hari pasar yang terjadi di Pasar Koto Baru ini jatuh pada hari Senin.. Ruas jalan yang menjadi penghubung pasar ini adalah Ruas Jalan Padang Panjang - Batas Kab. Agam. Volume lalu lintas diperoleh dari survai pencacahan lalu lintas terklasifikasi. Berdasarkan hasil perhitungan volume total lalu lintas dua arah pada Ruas Jalan Padang Panjang - Batas Kab. Agam adalah sebesar 2068.40 smp/jam. Kemudian Berdasarkan hasil perhitungan kapasitas total pada Ruas Jalan Padang Panjang - Batas Kab. Agam adalah sebesar $2346.60 \mathrm{smp} / \mathrm{jam}$.

Berdasarkan hasil perhitungan diatas dapat diketahui bahwa V/C Ratio Ruas Jalan Padang Panjang - Batas Kab. Agam sebesar 0,88 hal ini dikarenakan pengaruh faktor kesesuaian hambatan samping yang sangat tinggi di kawasan pasar tersebut. Ini berarti terjadinya permasalahan pada kinerja ruas jalan sehingga perlunya kajian lebih lanjut untuk melakukan peningkatan kinerja ruas jalan untuk mewujudkan kelancaran dalam berlalu lintas.

b) Kecepatan Arus Bebas

1) Kecepatan Arus Bebas

Perhitungan kecepatan arus bebas merupakan indikator penting kinerja ruas jalan dalam menerapkan manajemen lalu lintas pada Kawasan Koto Baru yang dapat mempengaruhi kelancaran arus lalu lintas. Untuk menghitung kecepatan arus lalu lintas digunakan rumus :

$\mathrm{FV}=(\mathrm{FVo}+\mathrm{FVw}) \times \mathrm{FFV}$ sf $\times$ FFV cs

$=(42+1,5) \times 0,88 \times 0,90$

$=34,46 \mathrm{~km} / \mathrm{jam}$

2) Kecepatan Perjalanan 
Perhitungan kecepatan perjalanan Ruas Jalan Padang Panjang - Batas Kab. Agam menggunkan rumus :

$$
\begin{aligned}
\mathrm{V} & =\mathrm{FV} \times 0,5\left(1+(1-\mathrm{V} / \mathrm{C})^{0,5}\right) \\
& =34,46 \times 0,5\left(1+(1-0,88)^{0,5}\right) \\
& =23,19 \mathrm{~km} / \mathrm{jam}
\end{aligned}
$$

Berdasarkan hasil dari analisa diatas, maka dapat diketahui kecepatan perjalanan pada Ruas Jalan Padang Panjang - Batas Kab. Agam adalah sebesar 23,19 km/jam.

c) Kepadatan Pada Ruas Jalan

Berikut ini merupakan kepadatan dari Ruas Jalan Padang Panjang - Batas Kab.

Agam adalah sebagai berikut :

Kepadatan $=\frac{\text { Volume }}{\text { Kecepatan }}$

$$
\begin{aligned}
& =\frac{2068,40}{23,19} \\
& =\quad 89,19 \mathrm{smp} / \mathrm{km}
\end{aligned}
$$

Berdasarkan hasil dari analisa diatas, maka dapat diketahui kepadatan pada Ruas Jalan Padang Panjang - Batas Kab. Agam adalah sebesar 89,19 smp/km.

d) Kapasitas Ruang Parkir

1) Akumulasi Parkir

Akumulasi parkir tertinggi di Ruas Jalan Padang Panjang - Batas Kab. Agam dengan sudut parkir $90^{\circ}$ dengan jumlah kendaraan parkir sebanyak 48 kendaraan untuk sepeda motor dan mobil yang terjadi pada pukul 07.30 07.45 WIB. Sedangkan, Akumulasi parkir tertinggi dengan sudut parkir $0^{\circ}$ dengan jumlah kendaraan parkir sebanyak 20 kendaraan yang terjadi pukul

\begin{tabular}{|c|c|c|c|c|}
\hline Nama Jalan & Panjang Jalan & Sudut & $\begin{array}{c}\text { Lebar Kaki Ruang } \\
\text { Parkir }\end{array}$ & Kapasitas Statis \\
\hline \multirow{6}{*}{$\begin{array}{l}\text { Jalan Padang } \\
\text { Panjang-Batas } \\
\text { Kab. Agam II }\end{array}$} & \multirow{6}{*}{100} & 0 & 6 & 17 \\
\hline & & 30 & 5 & 20 \\
\hline & & & & \\
\hline & & 45 & 3.7 & 27 \\
\hline & & 60 & 3 & 33 \\
\hline & & 90 & 2.5 & 40 \\
\hline \multirow{5}{*}{$\begin{array}{c}\text { Jalan Padang } \\
\text { Panjang-Batas } \\
\text { Kab. Agam I }\end{array}$} & \multirow{5}{*}{24} & 0 & 6 & 4 \\
\hline & & 30 & 5 & 5 \\
\hline & & 45 & 37 & 6 \\
\hline & & 60 & 3 & 8 \\
\hline & & 90 & 2.5 & 10 \\
\hline
\end{tabular}
$07.30-07.45$ WIB.

2) Kapasitas Statis

Kapasitas statis untuk lokasi parkir pada wilayah studi adalah sebagai berikut:

Tabel 1. Kapasitas Parkir Mobil Penumpang Gol II 
Adapun kapasitas statis pada ruas Jalan Padang Panjang - Batas Kab. Agam I untuk sepeda Motor dengan sudut $90^{\circ}$ adalah sebagai berikut:

Tabel 2. Kapasitas Parkir Sepeda Motor (Sudut 90 ${ }^{\circ}$ )

\begin{tabular}{|c|c|c|c|}
\hline Nama Jalan & $\begin{array}{c}\text { Panjang } \\
\text { Jalan (m) }\end{array}$ & $\begin{array}{c}\text { Lebar Kaki Ruang } \\
\text { Parkir }\end{array}$ & $\begin{array}{c}\text { Kapasistas } \\
\text { Statis }\end{array}$ \\
\hline Jalan Padang Panjang-Batas Kab. Agam I & 24 & 0.75 & 32 \\
\hline
\end{tabular}

3) Durasi Parkir

Berikut adalah adalah tabel perhitungan rata -rata durasi parkir pada ruas Jalan Padang Panjang - Batas Kab. Agam:

Tabel 3. Rata-rata Durasi Parkir Pada Ruas Jalan Padang Panjang - Batas Kab. Agam

\begin{tabular}{|c|c|c|c|}
\hline \multirow{2}{*}{ No } & \multirow{2}{*}{ Nama Jalan } & \multicolumn{2}{c|}{ Rata-rata durasi Parkir (Jam) } \\
\cline { 3 - 4 } & & Mobil & Motor \\
\hline 1 & Jl. Padang Panjang - Batas Kab. Agam I & - & 0.99 \\
\hline 2 & Jl. Padang Panjang - Batas Kab. Agam II & 1.22 & - \\
\hline 3 & Jl. Padang Panjang - Batas Kab. Agam I & 1.13 & - \\
\hline
\end{tabular}

4) Kapasitas Dinamis

Kapasitas dinamis tergantung pada besarnya rata-rata durasi atau lamanya kendaraan parkir. Berikut adalah kapasitas dinamis jalan diwilayah studi yang dapat dilihat pada tabel di bawah ini:

Tabel 4. Kapasitas Dinamis

\begin{tabular}{|c|c|c|c|c|c|}
\hline No & Nama Jalan & $\begin{array}{c}\text { Jenis } \\
\text { Kendaraan }\end{array}$ & $\begin{array}{c}\text { Sudut } \\
\text { Parkir }\end{array}$ & $\begin{array}{c}\text { Panjang } \\
\text { efektif parkir } \\
(\mathbf{m})\end{array}$ & $\begin{array}{c}\text { Kapasitas } \\
\text { Dinamis } \\
\text { (Ruang) }\end{array}$ \\
\hline 1 & $\begin{array}{c}\text { Jl. Padang Panjang - } \\
\text { Batas Kab. Agam I }\end{array}$ & Motor & 90 & 24 & 387 \\
\hline 2 & $\begin{array}{c}\text { Jl. Padang Panjang - } \\
\text { Batas Kab. Agam II }\end{array}$ & Mobil & 0 & 100 & 164 \\
\hline 3 & $\begin{array}{c}\text { Jl. Padang Panjang - } \\
\text { Batas Kab. Agam I }\end{array}$ & Mobil & 90 & 24 & 106 \\
\hline
\end{tabular}

5) Volume Parkir

Volume parkir merupakan jumlah keseluruhan kendaraan yang menggunakan fasilitas parkir di badan jalan per satuan waktu selama 12 jam (waktu penelitian) dengan interval waktu 15 menit. Volume parkir pada masingmasing ruas jalan dapat dilihat pada Tabel dibawah:

Tabel 5. Data Volume Parkir

\begin{tabular}{|c|c|c|}
\hline \multirow{2}{*}{ Lokasi Parkir } & \multicolumn{2}{|c|}{ Volume Kendaraan Parkir (Kend) } \\
\cline { 2 - 3 } & Sepeda Motor & Mobil Penumpang Gol. II \\
\hline $\begin{array}{c}\text { Jl. Padang Panjang - Batas Kab. } \\
\text { Agam }\end{array}$ & 199 & 227 \\
\hline
\end{tabular}


6) Indeks Parkir

Adalah penggunaan ruang parkir pada setiap waktu atau perbandingan antara akumulasi parkir dengan kapasitas parkir. Hasil perhitungan indeks parkir dapat dilihat pada tabel di bawah:

Tabel 6. Indeks Parkir

\begin{tabular}{|c|c|c|c|c|c|c|c|}
\hline \multirow{2}{*}{ Nama Jalan } & \multirow{2}{*}{$\begin{array}{c}\text { Panjang } \\
\text { Efektif } \\
\text { Parkir }\end{array}$} & \multicolumn{2}{|c|}{$\begin{array}{c}\text { Jumlah Petak } \\
\text { Parkir }\end{array}$} & \multicolumn{2}{c|}{$\begin{array}{c}\text { Akumulasi } \\
\text { Maksimal }\end{array}$} & \multicolumn{2}{c|}{ Indeks Parkir (\%) } \\
\cline { 3 - 8 } & & Mobil & Motor & Mobil & Motor & Mobil & Motor \\
\hline $\begin{array}{c}\text { Jl. Padang Panjang - Batas Kab. } \\
\text { Agam I }\end{array}$ & 42 & - & 32 & - & 33 & - & 103.1 \\
\hline $\begin{array}{c}\text { Jl. Padang Panjang - Batas Kab. } \\
\text { Agam II }\end{array}$ & 25 & 17 & - & 20 & - & 120.0 & - \\
\hline $\begin{array}{c}\text { Jl. Padang Panjang - Batas Kab. } \\
\text { Agam I }\end{array}$ & 45 & 10 & - & 15 & - & 150.0 & - \\
\hline
\end{tabular}

7) Tingkat Pergantian Parkir (TurnOver)

Survai patroli parkir yang telah dilakukan dapat diketahui volume kendaraan yang menggunakan fasilitas selama waktu survai. Perhitungan ini erat kaitannya dengan kapasitas dan penawaran yang tersedia. Dari kedua komponen tersebut akan diperoleh tingkat pergantian parkir atau turn over. Jadi perbandingan volume parkir untuk suatu periode waktu tertentu dengan jumlah ruang/kapasitas statis pada ruas Jalan Padang Panjang - Batas Kab. Agam I adalah sebagai berikut:

Tabel 7. Tingkat Pergantian Parkir

\begin{tabular}{|c|c|c|c|c|c|c|c|}
\hline \multirow{2}{*}{ Nama Jalan } & \multirow{2}{*}{$\begin{array}{c}\text { Panjang } \\
\text { Efektif } \\
\text { Parkir }\end{array}$} & \multicolumn{2}{|c|}{ Kapasitas Parkir } & \multicolumn{2}{c|}{$\begin{array}{c}\text { Volume } \\
\text { Kendaraan }\end{array}$} & \multicolumn{2}{c|}{ TO (kali) } \\
\cline { 3 - 8 } & 42 & Mobil & Motor & Mobil & Motor & Mobil & Motor \\
\hline $\begin{array}{c}\text { Jl. Padang Panjang - Batas Kab. } \\
\text { Agam I }\end{array}$ & 42 & 17 & - & 120 & - & 7.2 & - \\
\hline $\begin{array}{c}\text { Jl. Padang Panjang - Batas Kab. } \\
\text { Agam II }\end{array}$ & 25 & 10 & - & 106 & - & 10.6 & - \\
\hline $\begin{array}{c}\text { Jl. Padang Panjang - Batas Kab. } \\
\text { Agam I }\end{array}$ & 45 & 10 & - & 110 & - \\
\hline
\end{tabular}

\section{Skenario Penanganan}

Untuk dapat menerapkan manajemen dan rekayasa lalu lintas pada Kawasan Pasar Koto Baru maka dilakukan beberapa penanganan demi kelancaran lalu lintas pada Ruas Jalan Padang Panjang - Batas Kab. Agam adalah sebagai berikut:

a) Penataan Pedagang yang Berjualan di Bahu Jalan

Pedagang yang menjual barang dagangannya di bahu jalan perlu diadakannya penataan agar tidak terjadi pasar tumpah sehingga dapat menurunkan unjuk kerja pada ruas jalan di sekitar pasar. Penataan pedagang dilakukan untuk mencegah pasar tumpah ke jalan raya sehingga menganggu arus lalu lintas pada sekitar kawasan Pasar Koto Baru.

b) Penyediaan Fasilitas Parkir di Luar Ruang Milik Jalan

Berdasarkan Peraturan Pemerintah Nomor 79 Tahun 2013 pada pasal 105 ayat (1) menyatakan fasilitas parkir di dalam ruang milik jalan hanya diselenggarakan di tempat tertentu pada jalan kabupaten, jalan desa, atau jalan kota yang harus dinyatakan dengan Rambu Lalu Lintas dan /atau Marka Jalan. Dikarenakan ruas jalan di kawasan Pasar Koto Baru merupakan ruas jalan nasional, maka 
diperlukannya kajian pemindahan lokasi parkir dari parkir on street menjadi parkir off street.

Setelah melakukan perhitungan analisis kebutuhan luas lahan parkir, di ketahui bahwa total luas lahan yang di butuhkan untuk parkir di kawasan Pasar Koto Baru adalah 1429 meter $^{2}$.

c) Penyediaan Fasilitas Pejalan Kaki

Terdapat tiga titik yang dilakukan pengamatan yang memiliki potensi pejalan kaki untuk menyeberang yaitu Titik 1, Titik 2 dan Titik 3 . Titik 1 merupakan daerah pengamatan pejalan kaki menyeberang yang dilakukan di depan area parkir off street yang akan direncanakan. Titik 2 merupakan daerah pengamatan pejalan kaki yang dilakukan setelah Pasar Koto Baru pada ruas jalan menuju Kabupaten Agam. Titik 3 merupakan daerah pengamatan pejalan kaki di depan pintu masuk Pasar Koto Baru.

Berdasarkan hasil analisis, rata - rata kriteria penyeberangan pada titik 1 sebesar 14137356 atau $<10^{8}$. Maka fasilitas penyeberangan yang tepat yang diperlukan pada titik 1 ialah menggunakan zebra cross. Berdasarkan hasil analisis, rata - rata kriteria penyeberangan pada titik 2 sebesar 11831531 atau $<10^{8}$. Maka fasilitas penyeberangan yang tepat yang diperlukan pada titik 2 ialah menggunakan zebra cross. Pada titik 3 tidak dimungkinkan untuk direncanakan fasilitas penyeberangan karena direncanakan pada ruas jalan di depan Pasar Koto Baru akan dipasang pagar pembatas dengan median untuk menghindari terjadinya pasar tumpah pada hari pasar di Pasar Koto Baru.

\section{Analisa Setelah Dilakukan Penanganan}

a) Kapasitas Ruas Jalan

Peningkatan kapasitas ruas jalan terjadi setelah dilakukannya penataan kawasan Pasar Koto Baru dan dihilangkannya hambatan samping pada ruas jalan tersebut. Adapun perhitungan kapasitas ruas jalan setelah dilakukan penanganan sebagai berikut:

Tabel 8. Kapasitas Ruas Jalan Setelah Penanganan

\begin{tabular}{|c|c|c|c|c|c|c|}
\hline Nama Jalan & Co & FCw & FCsf & FCsp & FCcs & C (smp/jam) \\
\hline $\begin{array}{c}\text { Jalan Pandang Panjang - Batas Kab. } \\
\text { Agam }\end{array}$ & 2900 & 1.14 & 1.01 & 1 & 0.86 & 2871.59 \\
\hline
\end{tabular}

b) V/C Ratio Ruas Jalan

V/C Ratio adalah perbandingan antara volume kendaraan dengan kapasitas ruas jalan. Adapun V/C Ratio ruas jalan setelah dilakukan penanganan adalah sebagai berikut:

Tabel 9. V/C Ratio Ruas Jalan Setelah Penanganan

\begin{tabular}{|c|c|c|c|c|c|c|c|c|}
\hline Nama Jalan & Co & FCw & FCsf & FCsp & FCes & C (smp/jam) & Voulme & $\begin{array}{c}\text { V/C } \\
\text { Ratio }\end{array}$ \\
\hline $\begin{array}{c}\text { Jalan Pandang } \\
\text { Panjang - Batas } \\
\text { Kab. Agam }\end{array}$ & 2900 & 1.14 & 1.01 & 1 & 0.86 & 2871.59 & 2068.40 & 0.72 \\
\hline
\end{tabular}

c) Kecepatan Perjalanan

Perhitungan kecepatan arus bebas merupakan indikator penting kinerja ruas jalan dalam menerapkan manajemen lalu lintas pada Kawasan koto Baru yang dapat 
mempengaruhi kelancaran arus lalu lintas. Untuk menghitung kecepatan arus lalu lintas digunakan rumus:

$\mathrm{FV}=(\mathrm{FVo}+\mathrm{FVw}) \times$ FFVsf $\times$ FFVcs

$$
\begin{aligned}
& =(42+1,5) \times 0.99 \times 0,90 \\
& =38,76 \mathrm{~km} / \mathrm{jam}
\end{aligned}
$$

Perhitungan kecepatan perjalanan Ruas Jalan Padang Panjang - Batas Kab. Agam menggunkan rumus:

$\mathrm{V}=\mathrm{FV} \times 0,5\left(1+(1-\mathrm{V} / \mathrm{C})^{0,5}\right)$

$$
=38.76 \times 0,5\left(1+(1-0,72)^{0,5}\right)
$$$$
=29,63 \mathrm{~km} / \mathrm{jam}
$$

d) Kepadatan Ruas Jalan

Berikut ini merupakan kepadatan dari Ruas Jalan Padang Panjang - Batas Kab.

Agam setelah dilakukan penanganan adalah sebagai berikut:

$$
\begin{aligned}
\text { Kepadatan } & =\frac{\text { Volume }}{\text { Kecepatan }} \\
& =\frac{2068,40}{29,63} \\
& =69,81 \mathrm{smp} / \mathrm{km}
\end{aligned}
$$

\section{KESIMPULAN}

Berdasarkan hasil analisis data yang telah dilakukan maka dapat ditarik kesimpulan sebagai berupa unjuk kerja Ruas Jalan Padang Panjang - Batas Kab.Agam eksisting pada hari pasar memiliki $\mathrm{V} / \mathrm{C}$ ratio sebesar 0,88 dengan kecepatan perjalanan sebesar 23,19 km/jam. Kemudian terjadinya peningkatan unjuk kerja Ruas Jalan Padang Panjang - Batas Kab.Agam pada hari pasar setelah dilakukannya manajemen dan rekayasa lalu lintas V/C ratio sebesar 0,72 dengan kecepatan perjalanan sebesar 29,63 $\mathrm{km} / \mathrm{jam}$. Kepadatan Ruas Jalan Padang Panjang - Batas Kab.Agam pada hari pasar mencapai 89,19 smp/km dengan tingkat pelayanan D. Terakhir akumulasi parkir tertinggi di Ruas Jalan Padang Panjang - Batas Kab. Agam dengan sudut parkir $90^{\circ}$ dengan jumlah kendaraan parkir sebanyak 48 kendaraan untuk sepeda motor dan mobil yang terjadi pada pukul 07.30 - 07.45 WIB. Sedangkan, Akumulasi parkir tertinggi dengan sudut parkir $0^{\circ}$ dengan jumlah kendaraan parkir sebanyak 20 kendaraan yang terjadi pukul $07.30-07.45$ WIB.

\section{DAFTAR PUSTAKA}

1. Kelompok PKL Kabupaten Tanah Datar. 2016. Laporan Umum Taruna Sekolah Tinggi Transportasi Darat Program Studi Diploma III Lalu Lintas dan Angkutan Jalan. Pola umum Lalu Lintas dan Angkutan Darat di Wilayah Studi Kabupaten Tanah Datar dan Identifikasi Permasalahannya

2. Morlok, Edward K. (1991). Pengantar Teknik dan Perencanaan Transportasi. Jakarta: Erlangga.

3. Munawar, Ahmad. (2006). Manajemen Lalu Lintas Perkotaan, Beta Offset. Yogyakarta.

4. Munawar, Ahmad. 1997. Manual Kapasitas Jalan Indonesia, Sweroad \& Bina Karya 
5. Republik Indonesia. 2009. Undang-Undang Nomor 22 Tahun 2009 tentang Lalu Lintas dan Angkutan Jalan. Jakarta: Departemen Perhubungan.

6. Republik Indonesia. 2011. Peraturan Pemerintah Nomor 32 Tahun 2011 tentang Manajemen dan Rekayasa, Analisis Dampak Serta Manajemen Kebutuhan Lalu Lintas.

7. Republik Indonesia. 2013. Peraturan Pemerintah 79 tahun 2013 tentang Jaringan Lalu Lintas dan Angkutan Jalan

8. Republik Indonesia. 2015. PM 96 tahun 2015 tentang Pedoman Teknis Pelaksanaan Kegiatan Manajemen dan Rekayasa Lalu Lintas.

9. Republik Indonesia,Dinas PU. Tata Cara Perencanaan Fasilitas Pejalan Kaki di Kawasan Perkotaan 